Рудюк Олег

кандидат психологічних наук, доцент кафедри загальної психології та психодіагностики Рівненського державного гуманітарного університету http://orcid.org/0000-0003-0200-1982 DOI https://doi.org/10.35619/praprv.v1i15.195

\title{
ОСОБЛИВОСТІ САМОРЕГУЛЯЩЇ̈ МАЙБУТНІХ ПСИХОЛОГІВ НА РІЗНИХ ЕТАПАХ ЇХ ФАХОВОЇ ПІДГОТОВКИ
}

\begin{abstract}
Анотація. В статті представлено результати дослідження стильових особливостей саморегулящії поведінки майбутніх фахівців-психологів на різних етапах їх фахової підготовки. За результатами проведеного дослідження виявлено, шо характер розвитку основних регуляторних процесів (планування цілей діяльності, моделювання значущих умов, програмування дій, оцінка $і$ корекиія результатів) та регуляторноособистісних властивостей (гнучкість і самостійність) майбутніх фахівиів-психологів має свої специфічні особливості на різних етапах їх учбово-професійної підготовки.

Виявлено, щзо у порівнянні зі студентами першого курсу, у студентів четвертого курсу спостерігається достовірно вищий ступінь розвитку основних регуляторних процесів та регуляторно-особистісних властивостей: загального рівня саморегулячії як здатності до усвідомленої саморегуляиії довільної активності; гнучкості як здатності до перебудови та корекції системи саморегуляиї при зміні зовнішніх і внутрішніх умов; оцінки $і$ корекцї результатів як здатності до адекватної та автономної оцінки себе і результатів своєї діяльності та поведінки; моделювання значущих умов як ступеня розвитку уявлень про систему зовнішніх і внутрішньо значущих для досягнення иілей умов, їх усвідомленості та деталізованості; самостійності як ступеня розвитку регуляторної автономності; програмування дій як ступеня усвідомленої побудови способів і послідовності власних дій для досягнення поставлених иілей; планування цілей діяльності як ступеня розвитку механізмів цілепокладання з точки зору усвідомленості й автономності процесу висунення ияілей активності, їх дієвості, реалістичності, деталізованості та стійкості.
\end{abstract}

Ключові слова: саморегуляція, саморегулячія поведінки, регуляторні прочеси, регуляторно-особистісні властивості, компоненти саморегуляиї поведінки, студентипсихологи, фахова підготовка.

Постановка проблеми. Трансформація вітчизняної сфери вищої освіти відповідно до європейських стандартів пред’являє високі вимоги до особистості майбутнього фахівця та розвитку його загальних і спеціальних компетентностей, які дозволять долати труднощі об'єктивного і суб'єктивного характеру у процесі учбово-професійної підготовки. У цьому процесі здобувач вищої освіти розглядається як суб'єкт ініціації власної довільної і усвідомленої активності в напрямку забезпечення оптимальної регуляції взаємовідносин 3 освітнім середовищем. Одним із найбільш загальних і суттєвих проявів такої суб'єктної позиції майбутнього фахівця є здатність до саморегуляції власної поведінки в умовах навчальної діяльності. Успішна саморегуляція суб'єктів освітнього процесу у вищій школі забезпечує необхідний рівень оптимальної мобілізації власних потенційних можливостей у напрямку розвитку професійних здібностей, актуалізації і реалізації їх особистісного та інтелектуального потенціалу.

Особливого значення здатність до саморегуляції власної поведінки в умовах навчальної діяльності набуває у системі фахової підготовки майбутніх фахівців соціономічного профілю, зокрема, майбутніх психологів. Здатність до саморегуляції поведінки стає не лише визначальним чинником ефективного вирішення актуальних проблем і задач їх навчальної діяльності, але і професійно важливою якістю у структурі їх професійної компетентності. Незважаючи на репрезентативний теоретичний та емпіричний 
досвід розробки проблеми саморегуляції поведінки майбутніх фахівців в умовах їх навчальної діяльності, фактично відсутні розвідки, присвячені вивченню особливостей саморегуляції поведінки майбутніх фахівців-психологів на різних етапах їх фахової підготовки.

Аналіз останніх досліджень 3 проблеми. У сучасній психології розробці різних аспектів проблеми саморегуляції присвячені праці Боришевського, Конопкіна, Максименка, Миславського, Моросанової, М'ясищева, Осницького, Пов'якель, Трофімова та ін. Стильові характеристики саморегуляції стали фокусом дослідницьких інтересів Коноз, Моросанової, Сагієва та ін. Вольові компоненти саморегуляції стали предметом вивчення Іваннікова, Котрило; емоційні - Рейковського, Саннікової; моральні - Кириченко, Якобсона; мотиваційні -Ксенофонтової, Степанського, Файзуллаєва; особистісні - АбульхановоїСлавської, Орбан-Лембрик, Чеснокової; інтелектуальні - Моляко, Тихомирова; ціннісносмислові - Долинської, Кона, Семенова, Ядова; рефлексивні - Беха, Зака, Зейгарнік, Поліванової.

Система саморегуляції має певну структурну організацію. В якості основних структурних елементів саморегуляції виокремлюють: зміст, процес, самооцінку (Моросанова, 2010). Зокрема, змістовими структурними елементами саморегуляції виступають джерела активності особистості, iï внутрішня мотивація; процесуальні структурні елементи саморегуляції пов'язані з тими чи іншими варіантами регуляції діяльності на певному рівні досягнень; основу самооцінювання складають мотиви, спрямованість, засоби та оцінка результатів діяльності.

Для вивчення індивідуально-типологічних особливостей системи регуляції довільної активності особистості запропоновано поняття «індивідуального стилю саморегуляції». До стильових особливостей саморегуляції входять індивідуальні особливості регуляторних процесів - цілі, моделювання умов, програмування дій, оцінювання результатів, а також стильові особливості (регуляторно-особистісні властивості) - самостійність, ініціативність, гнучкість (Моросанова, 2010).

Індивідуальний стиль саморегуляції, який характеризується рівнем розвитку регуляторних процесів та регуляторних властивостей особистості, забезпечує необхідну основу для формування системи особистісних компетентностей майбутніх фахівців, які визначатимуть якість їх фахової підготовки: вміння ставити цілі і визначати найбільш пріоритетні 3 них, аналізувати умови і виділяти найбільш важливі 3 них для досягнення поставленої мети, вибирати оптимальні способи дій і організовувати їхню послідовну реалізацію, оцінювати проміжні та кінцеві результати діяльності, корегувати власну діяльність.

У вітчизняній науково-психологічній традиції особливості саморегуляції поведінки майбутніх фахівців в процесі їх навчальної діяльності є предметом вивчення Василенко, Васильєвої, Войтюка, Гринціва, Дячок, Зимньої, Моросанової, Нещерет, Т. Партико, Тесленко, Токаревої, Шавиро, Н. Юдіної та ін. Вивчення процесів і механізмів саморегуляції у навчальній діяльності студентів у зарубіжній науково-психологічній традиції представлена розробками Шунка, Ертмера, Бокартса, Пінтріха, Зайднера (саморегуляція i самоефективність студентів); Циммермана (саморегуляція і мотивація навчальної діяльності студентів); Забруцькі, Шроу, Гріппен, Реса (метакогнітивні аспекти дослідження саморегуляції навчальної діяльності); Сана, Руеди (поведінкові, емоційні та когнітивні аспекти саморегуляції студентів) та ін.

Система саморегуляції поведінки майбутніх фахівців у процесі їх учбової (навчальної) діяльності має ту ж структуру, що і саморегуляція будь-якої іншої діяльності. Структурними компонентами саморегуляції поведінки майбутніх фахівців виступають: планування, визначення мети навчальної діяльності та послідовності здійснення цілей навчання; моделювання, урахування значущих умов навчальної діяльності, необхідних для iї виконання; програмування та визначення послідовності виконання дій навчальної діяльності; оцінка результатів та їх співвідношення з критеріями, визначеними викладачем чи самим 
студентом; контроль за результатами та корекція навчальних дій на основі індивідуально прийнятих еталонів успішності (Моросанова, 1994).

В контексті обгрунтування структури саморегуляції майбутніх фахівців використовують поняття «професійної саморегуляції» (Чайка, 2006). В якості компонентів професійної саморегуляції майбутніх фахівців виокремлюють: мотиваційний, який відображає усвідомлені студентами моральні поняття, загальнокультурні та професійнопедагогічні цінності, спрямовані на оволодіння професією; рефлексивний, який передбачає порівняння студентом свого досвіду з досвідом інших людей; емоційно-вольовий, який полягає в умінні виявляти витримку, усвідомлювати власні почуття, регулювати свої стосунки та спілкуватися; діяльнісний, який передбачає вміння студента здійснювати самоконтроль, самокорекцію поведінки, усвідомлювати мету власних дій.

Високий рівень розвитку процесів саморегуляції у студентів пов'язаний з докорінною трансформацією їх ставлення до власної навчальної діяльності. Майбутній фахівець не просто передбачає результати своїх дій, але i починає довільно організовувати їх: формулювати і обгрунтовувати цілі, аналізувати їх з точки зору значущості та можливості досягнення, створювати нові способи їх здійснення. Він не просто контролює свої дії шляхом порівняння їх результатів з еталоном, але й визначає різноманітні критерії, показники контролю і оцінки. Тобто, майбутній фахівець починає опановувати процес управління власною навчальною діяльністю.

Саморегуляція поведінки студентів в процесі їх учбово-професійної підготовки відбувається у площині двох взаємопов'язаних процесів. 3 одного боку, процеси саморегуляції спрямовані на регуляцію актуальної навчальної діяльності майбутнього фахівця, тобто вирішення поточних задач і проблем, що виникають в процесі його учбовопрофесійної підготовки, а 3 іншого, - на розвиток системи фахових знань, вмінь та здібностей як основи для повного i максимального розкриття його особистісного i професійного потенціалу. Відтак вивчення психологічних особливостей і закономірностей саморегуляції поведінки майбутніх фахівців у процесі учбово-професійної діяльності стає важливим фактором розуміння не лише умов забезпечення якості їх фахової підготовки, але i умов формування системи їх особистісних компетентностей.

Мета статті полягає у дослідженні особливостей саморегуляції поведінки майбутніх фахівців-психологів на різних етапах їх фахової підготовки.

Методика та організація дослідження. В ході емпіричного дослідження перевірялась гіпотеза про те, що характер саморегуляції поведінки майбутніх фахівцівпсихологів має свої специфічні особливості прояву на різних етапах їх фахової підготовки. Її перевірку було здійснено за участю студентів-психологів старшого (IV-го) і молодшого (I-го) курсів навчання. Репрезентативна вибірка випробуваних у кількості 72 осіб була сформована методом рандомізованого відбору з числа здобувачів вищої освіти Рівненського державного гуманітарного університету.

3 метою вивчення особливостей саморегуляції поведінки майбутніх фахівцівпсихологів на різних етапах їх фахової підготовки було використано опитувальник В. Моросанової «Стиль саморегуляції поведінки» (Моросанова, 2004). Опитувальник в цілому працює як єдина шкала «загальний рівень саморегуляції» і складається 346 тверджень, що входять до складу шести шкал, які виділяються відповідно до основних регуляторних процесів і регуляторно-особистісних властивостей. Емпіричними показниками, які вимірювались у випробуваних в ході дослідження, було визначено: «планування иілей діяльності», який характеризує індивідуальні особливості цілепокладання 3 точки зору усвідомленості й автономності процесу висунення цілей активності, їх дієвості, реалістичності, стійкості, деталізованості; «моделювання значущих умов», який відображає розвиненість уявлень про систему зовнішніх і внутрішньо значущих для досягнення цілей умов, ступінь їх усвідомленості, деталізованості й адекватності; «програмування дій», що полягає в усвідомленій побудові суб'єктом способів і послідовності власних дій для досягнення поставлених цілей; «оцінка $і$ корекція результатів», що відображає адекватність, автономність оцінки себе і результатів своєї діяльності та поведінки, стійкість суб'єктивних 
критеріїв оцінки успішності досягнення результатів; «гнучкість», що відображає рівень сформованості регулятивної гнучкості, тобто здатність перебудовувати, вносити корективи в систему саморегуляції при зміні зовнішніх і внутрішніх умов; «самостійність», що характеризує розвиненість регуляторної автономності; «загальний рівень саморегуляиїі», що оцінює загальний рівень сформованості індивідуальної системи усвідомленої саморегуляції довільної активності.

Аналіз даних було здійснено за допомогою методу порівняння середніх значень (Бююль, 2002) і непараметричного методу відмінностей для незалежних вибірок Манна-Вітні (Наследов, 2004).

Виклад основного матеріалу дослідження. За результатами проведення емпіричного дослідження було виявлено ряд важливих закономірностей (див. Табл. 1.). Враховуючи характер отриманих результатів, їх аналіз та інтерпретацію проведемо з урахуванням рівня достовірності виявлених закономірностей - від найбільш до найменш значимих результатів.

Відмінності середніх значень вираженості показників саморегуляцї̈ поведінки майбутніх психологів на різних етапах їх фахової підготовки

\begin{tabular}{|l|c|c|c|}
\hline \multicolumn{1}{|c|}{ Показники саморегуляції поведінки } & \multicolumn{2}{|c|}{ Курс підготовки } & \multicolumn{1}{|c|}{$\begin{array}{c}\text { Значення } \\
\text { ймірності } \\
\text { (р) }\end{array}$} \\
\cline { 2 - 3 } & перший & четвертий & 0,033 \\
\hline планування цілей діяльності & 4,56 & 5,25 & 0,007 \\
\hline моделювання значущих умов & 4,64 & 5,78 & 0,019 \\
\hline програмування дій & 5,47 & 6,56 & 0,004 \\
\hline оцінка і корекція результатів & 4,19 & 5,31 & 0,003 \\
\hline гнучкість & 5,53 & 7,03 & 0,008 \\
\hline самостійність & 6,19 & 7,72 & 0,000 \\
\hline загальний рівень саморегуляції & 30,58 & 37,64 & \\
\hline
\end{tabular}

На підставі аналізу табличних даних, можна констатувати, що статистично значимі відмінності у середніх значеннях вираженості показників саморегуляції поведінки майбутніх психологів виявлено у відношенні усіх порівнюваних характеристик: «загального рівня саморегулячіï» $(\mathrm{p} \leq 0,001)$, «гнучкості» $(\mathrm{p} \leq 0,01)$, «очінки $i$ корекиії результатів» $(\mathrm{p} \leq 0,01)$, «моделювання значущих умов» $(\mathrm{p} \leq 0,01)$, «самостійності» $(\mathrm{p} \leq 0,01)$, «програмування дій» $(\mathrm{p} \leq 0,05)$, «планування цілей діяльності» $(\mathrm{p} \leq 0,05)$.

Узагальнення результатів вивчення особливостей саморегуляції поведінки майбутніх психологів на різних етапах їх учбово-професійної підготовки дозволяє констатувати, що у порівнянні зі студентами-психологами першого курсу навчання, у студентів-психологів четвертого курсу спостерігається достовірно вищий ступінь сформованості індивідуальної системи усвідомленої саморегуляції довільної активності («загальний рівень саморегуляції»). Студенти-психологи демонструють більшу самостійність, гнучкість і адекватність реагування на зміну умов, у т.ч. пов'язаних з навчанням; висунення і досягнення мети у них в значній мірі усвідомлено. При високій мотивації досягнення вони здатні формувати такий стиль саморегуляції, який дозволяє компенсувати вплив особистісних, характерологічних особливостей, що перешкоджають досягненню мети; опановувати нові види активності, 
впевненіше почувати себе в незнайомих ситуаціях; демонструвати більш стабільні успіхи у звичних видах діяльності.

Очевидним $\epsilon$ i те, що у порівнянні зі студентами-психологами першого курсу навчання, у студентів-психологів четвертого курсу спостерігається достовірно вищий ступінь сформованості регулятивної гнучкості, тобто здатності перебудовувати, вносити корективи в систему саморегуляції при зміні зовнішніх і внутрішніх умов («гнучкість»). Студенти-психологи старшого курсу демонструють вищу пластичність усіх регуляторних процесів, що дозволяє їм у випадку виникнення непередбачуваних обставин, у т.ч. пов'язаних 3 їх навчальною діяльністю, легко перебудовувати плани i програми виконавських дій i поведінки, більш швидко оцінювати зміну значущих умов i перебудовувати програму дій; при виникненні неузгодженості отриманих результатів 3 прийнятою метою своєчасно оцінювати сам факт неузгодженості і вносити відповідні зміни; більш адекватно реагувати на швидку зміну подій і успішно вирішувати поставлену задачу в ситуації ризику.

У порівнянні зі студентами-психологами першого курсу навчання, у студентівпсихологів четвертого курсу спостерігається достовірно вищий ступінь адекватності, автономності оцінки себе і результатів своєї діяльності та поведінки, стійкості суб'єктивних критеріїв оцінки успішності досягнення результатів («оцінка і корекція результатів»). Вони більш адекватно оцінюють як сам факт неузгодженості отриманих результатів 3 метою діяльності, так і причини, що призвели до цього, гнучко адаптуючись до зміни умов.

Також, у порівнянні зі студентами-психологами першого курсу навчання, у студентівпсихологів четвертого курсу спостерігається достовірно вищий ступінь розвиненості уявлень про систему зовнішніх і внутрішньо значущих для досягнення цілей умов, ступінь їх усвідомленості, деталізованості, адекватності («моделювання значущих умов»). Вони здатні краще виділяти значущі умови досягнення цілей як в поточній ситуації, так і в перспективному майбутньому, що проявляється у відповідності програм дій планам діяльності, відповідно отриманих результатів прийнятим цілям.

У студентів-психологів четвертого курсу навчання у порівнянні зі студентамипсихологами першого курсу спостерігається достовірно вищий ступінь розвиненості регуляторної автономності («самостійність»). Це свідчить про їх кращу автономність в організації власної активності, більш розвинену здатність самостійно планувати діяльність і поведінку, організовувати роботу по досягненню визначеної мети, контролювати хід ії виконання, аналізувати і оцінювати як проміжні, так і кінцеві результати діяльності (в т.ч., навчальної). Також, у студентів-психологів четвертого курсу навчання у порівнянні зі студентами-психологами першого курсу спостерігається достовірно вищий ступінь усвідомленої побудови способів і послідовності власних дій для досягнення поставлених цілей («програмування дій»). У них в більшій мірі сформовані потреби продумувати способи своїх дій і поведінки для досягнення намічених цілей. У студентів четвертого курсу у порівнянні зі студентами першого курсу програми розробляються самостійно, вони гнучко змінюються в нових обставинах і стійкі в ситуації перешкод; у разі невідповідності отриманих результатів визначеним цілям проводиться більш ефективна корекція програми дій до отримання прийнятного для них результату.

Насамкінець, у студентів-психологів четвертого курсу навчання у порівнянні зі студентами-психологами першого курсу виявляється достовірно вищий ступінь розвитку індивідуальних механізмів цілепокладання 3 точки зору усвідомленості й автономності процесу висунення цілей активності, їх дієвості, реалістичності, стійкості, деталізованості («планування цілей діяльності»). Студенти старшого курсу навчання виявляють вищий ступінь сформованості потреби в усвідомленому плануванні діяльності; їх плани в цьому випадку більш реалістичні, деталізовані, ієрархічні і стійкі, цілі діяльності висуваються самостійно.

Висновки і перспективи подальших розвідок. За результатами проведеного емпіричного дослідження стало можливим стверджувати, що характер саморегуляції поведінки майбутніх фахівців-психологів має свої специфічні особливості прояву на різних 
етапах їх фахової підготовки. Було виявлено, що у порівнянні зі студентами-психологами молодшого курсу, у майбутніх фахівців-психологів старшого курсу навчання спостерігається вищий ступінь сформованості регуляторних процесів $\mathrm{i}$ регуляторно-особистісних властивостей. Зокрема, на конкретно-емпіричному рівні за усіма вимірюваними показниками студентів-психологів порівнюваних курсів навчання підтверджено статистично значимий характер відмінностей середніх значень їх вираженості.

Перспективу подальших розвідок вбачаємо в напрямку виявлення характеру залежності рівня сформованості регуляторних процесів і регуляторно-особистісних властивостей майбутніх психологів від особливостей та характеру їх учбово-професійної підготовки.

\section{СПИСОК ПОСИЛАНЬ}

Бююль, А. \& Цёфель, П. (2002). SPSS: искусство обработки информации: анализ статистических данных и восстановление скрытых закономерностей. СанктПетербург: ООО «ДиаСофтЮГ».

Моросанова, В. И. (1994). Диагностика индивидуально-стилевых особенностей саморегуляции в учебной деятельности студентов. Вопросы психологии, 4, 134-140.

Моросанова, В. И. (2004). Опросник «Стиль саморегуляичи поведения». Москва.

Моросанова, В. И. (2010). Саморегулящия и индивидуальность человека: Монография. Москва: Наука.

Наследов, А. Д. (2004). Математические методы психологического исследования: анализ и интерпретация данных. Санкт-Петербург: Речь.

Чайка, В. (2006). Підготовка майбутнього вчителя до саморегуляиії педагогічної діяльності: Монографія. Тернопіль: Тернопільський національний педагогічний університет.

\section{REFERENCES}

Byuyul, A. \& Tsyofel, P. (2002). SPSS: iskusstvo obrabotki informatsii: analiz statisticheskih dannyih $i$ vosstanovlenie skryityih zakonomernostey [SPSS: the art of information processing: analyzing statistical data and recovering hidden patterns]. Sankt-Peterburg: OOO «DiaSoftYuG». [in Russian].

Morosanova, V. I. (1994). Diagnostika individualno-stilevyih osobennostey samoregulyatsii v uchebnoy deyatelnosti studentov [Diagnostics of individual-style features of self-regulation in the educational activities of students]. Voprosyi psihologii, 4, 134-140. [in Ukrainian].

Morosanova, V. I. (2004). Oprosnik «Stil samoregulyatsii povedeniya» [Questionnaire «Style of self-regulation of behavior»]. Moskva. [in Russian].

Morosanova, V. I. (2010). Samoregulyatsiya i individualnost cheloveka: Monografiya [Selfregulation and individuality: Monograph]. Moskva: Nauka.

Nasledov, A. D. (2004). Matematicheskie metodyi psihologicheskogo issledovaniya: analiz $i$ interpretatsiya dannyih [Mathematical methods of psychological research: data analysis and interpretation]. Sankt-Peterburg: Rech. [in Russian].

Chayka, V. (2006). Pidgotovka maybutnyogo vchitelya do samoregulyatsiyi pedagogichnoyi diyalnosti: Monografiya [Preparation of the future teacher for self-regulation of pedagogical activity: Monograph]. Ternopil: Ternopilskiy natsionalniy pedagogichniy universitet. [in Ukrainian]. 


\title{
FEATURES OF SELF-REGULATION OF FUTURE PSYCHOLOGISTS AT DIFFERENT STAGES OF THEIR PROFESSIONAL TRAINING
}

\author{
Oleh Rudiuk \\ Candidate of Psychological Science, \\ assistant professor of the department of \\ general psychology and psychological diagnostics \\ Rivne State University of Humanities \\ http://orcid.org/0000-0003-0200-1982. \\ DOI https://doi.org/10.35619/praprv.v1i15.195
}

\begin{abstract}
The article deals with the results of research of the stylistic features of selfregulation of behavior of future specialists-psychologists at different stages of their training. The results of the study reveal that the nature of development of basic regulatory processes (goals planning, significant conditions modeling, actions programming, evaluation and correction of results) and regulatory individual properties (flexibility and independence) of future psychologists has its own specific features at different stages of their educational and professional training.

In comparison with the first-year psychology students, psychology students of the fourth year show significantly higher degree of development of basic regulatory processes and regulatory individual properties. That is: general level of self-regulation as the ability to conscious selfregulation of arbitrary activity; flexibility as the ability to restructure and correct the system of selfregulation when external and internal conditions change; evaluation and correction of results as the ability to adequately and autonomously evaluate themselves and the results of their activities and behavior, as well as the stability of subjective criteria for evaluating the success of achieving results; modeling of significant conditions as a degree of development of ideas about the system of external and internally significant conditions for achieving the goals, their awareness, detail, adequacy; independence as a degree of development of regulatory autonomy; programming of actions as a degree of conscious construction of ways and sequences of own actions for achievement of the set purposes; planning the goals of activity as a degree of development of goalsetting mechanisms in terms of awareness and autonomy of the process of setting goals for activity, their effectiveness, realism, detail and stability.

Key words: self-regulation, self-regulation of behavior, regulatory processes, regulatory individual characteristics, components of self-regulation of behavior, psychology students, professional training.
\end{abstract}

